\title{
Crowdfunding: The Collaborative Economy for Channelling Institutional and Household Savings
}

Jaume Roig Hernando

Department of Business Administration, Polytechnic University of Catalonia

e-mail: jaume.roig.hernando@upc.edu, T: +34 6052711 73, C/Vallespir, 141, 3ro, 1ra, Barcelona, 08014

\begin{abstract}
The financial disintermediation mechanism known as "loan-based-crowdfunding" has recently come under regulation in several countries. This competitive investment and finance vehicle is already well established in the US and British markets.

By compiling empirical data from a reference crowdfunding platform, this article compares loan-based crowdfunding with traditional investment vehicles such as investment funds, equities or pension funds.

The conclusion of the study is that saving through crowdfunding allows the optimization of a portfolio comprising both institutional and retail investors.
\end{abstract}

Keywords: Financial Markets, Collaborative Economy, Crowdfunding, Alternative Investment, Retail Investors, Retirement Plans, Small and Medium Enterprises (SMEs). 


\title{
Crowdfunding: The Collaborative Economy for Channelling Institutional and Household Savings
}

\begin{abstract}
The financial disintermediation mechanism known as "loan-based-crowdfunding" has recently come under regulation in several countries. This competitive investment and finance vehicle is already well established in the US and British markets.

By compiling empirical data from a reference crowdfunding platform, this article compares loan-based crowdfunding with traditional investment vehicles such as investment funds, equities or pension funds.
\end{abstract}

The conclusion of the study is that saving through crowdfunding allows the optimization of a portfolio comprising both institutional and retail investors.

Keywords: Financial Markets, Collaborative Economy, Crowdfunding, Alternative Investment, Retail Investors, Retirement Plans, Small and Medium Enterprises (SMEs).

JEL Codes: G11, G14, O3

\section{Introduction}

The financial markets have developed rapidly since the second half of the twentieth century. The increasing availability of information via the new technologies has resulted in a vast range of new forms of mortgages and of consumer credit, futures, options, swaps and other risk management vehicles, new forms of health insurance, and innovative ways of making development loans (Shiller, 2009).

However, financial markets present inefficiencies. Several of the innovative products mentioned above, for example, are beyond the reach of small and medium enterprises (SMEs) and households, and investment and finance alternatives for relatively small portfolios or small turnover companies are limited.

Moreover, these market inefficiencies are increased by an environment characterised by low interest rates, the strong negotiating power of financial suppliers with respect to SMEs and small investors because of the low number of organisations with systemic risk, and a European financial market that is highly dependent on its banking institutions (Giralt and González, 2012). While banks in the US account for only $19 \%$ of long term financing, in the European Union the corresponding figure is $81 \%$ (Cummings, 2013).

Several studies agree that well-functioning financial intermediaries have a significant impact on economic growth and that there is a positive correlation between economic growth 
and finance (Bonin and Wachtel, 2003, Goldsmith, 1969; King and Levine, 1993). As a result, the search for alternative financial suppliers in Europe is now underway (Roig and Soriano, 2015).

Measures such as the Bank of Spain's regulation of the upper limits of deposit interest rates in order to reduce the "war for deposits" are justified by the alleged risk to the finance industry, but they may result in other market interferences which mainly affect small investors (Valverde and Villarroya, 2010). In this context, along with an increase in the financial culture and the spread of information technology, new innovative vehicles are penetrating the market with households and SMEs as their main targets.

An example is the new investment and finance vehicle named loan-based crowdfunding, also known as crowdlending, which has quickly made its mark in the financial markets. In this system, individuals, organisations and businesses can raise money to finance their activities through online portals named crowdfunding platforms (Financial Conduct Authority, 2014).

Loan-based crowdfunding is being consolidated in the Anglo-Saxon countries with more than $\$ 4$ billion channelized through platforms and penetrating the Spanish market with potential of becoming a part of the solution of the financial market inefficiencies and an efficient risk-return asset for investors who are interested in diversify their portfolio. On the other hand, considering it is a new capital market product and, according to the World Economic Forum (2016), an innovation that would have a greater impact on the financial markets, little research has been done on crowdlending and, even more, from an investment perspective.

Given the potential of loan-based crowdfunding to become part of the solution to the problems faced by small investors, highlighting the scarcity of investment products, and to increase the democratisation of the financial markets, here we evaluate its impact on a savings portfolio.

\section{Methodology}

First, the following mathematical expression is used to determine the risk of the crowdlending investment product:

$$
\text { Risk }=\sigma^{2}=\frac{\left[\sum_{1}^{c}\left(R_{p}-E\left(R_{p}\right)\right)^{2}\right]}{n}
$$

Where $\sigma$ represents the standard deviation, $R_{p}$ the loan profitability. $E\left(R_{p)}\right.$ the expected return of historical loans and $n$ the number of historical loans.

Second, the following expression is applied to establish the risk of a loan-based crowdfunding portfolio. Bear in mind that it does not include systemic risk and that it hypothesises that there will be no correlation between the risk of default among SMEs due to their heterogeneity, since the companies are located in different regions and belong to clearly differentiated industries: 


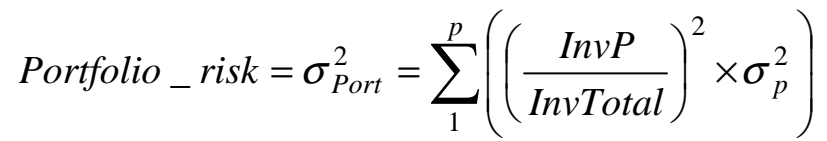

Where P corresponds to a particular loan, Port corresponds to the loan-based portfolio of any given investor, InvP to the amount invested in a particular loan, InvTotal to the total amount invested in crowdlending by a particular investor and $\sigma_{p}^{2}$ to the variance of a particular loan. follows:

In addition, in the case that $\mathrm{n}$ loans present the same risk, the portfolio risk will be as

$$
\text { Portfoliio_risk }=\sigma_{\text {Cart }}^{2}=\frac{\sigma^{2}}{n}
$$

Third, in order to determine the drivers that influence the loan-based crowdfunding return, a multiple linear regression is applied in order to model the relation between the dependent variable (Y), that is, the loan return, several independent variables (Var), and a randomised factor $(\varepsilon)$, expressed by the following equation:

$$
\mathrm{Y}_{1}\left(\operatorname{Var}_{\mathrm{i}}\right)=\alpha_{0}+\alpha_{1} \operatorname{Var}_{1}+\alpha_{2} \operatorname{Var}_{2}+\alpha_{3} \operatorname{Var}_{3}+\alpha_{4} \operatorname{Var}_{4}+\ldots+\alpha_{n} \operatorname{Var}_{n}+\varepsilon
$$

Where $Y_{1}$ corresponds to the dependent variable, $\alpha_{0}$ corresponds to the intersection or constant factor, $\alpha_{\mathrm{i}}$ measure the relationship between independent variables and the dependent variable and $\operatorname{Var}_{i}$ to the independent variables.

Fourth, compound interest is used to calculate the profitability of the pension funds. Interest is calculated on the initial principal and also on the accumulated interest of a deposit or loan over previous periods.

$$
C_{f}=C_{f}(1+r)^{n}
$$

Where $C_{F}$ corresponds to the capital in the final period, $C_{I}$ to the start-up capital, $r$ to the interest rate and $n$ to the number of periods.

The expression used to calculate the compound interest rate is the following:

$$
\mathrm{r}_{\mathrm{t}}=(1+\mathrm{r})^{\mathrm{n}}-1
$$

Where $r_{T}$ represent the compound annual growth rate.

Fifth, the debt ratio is applied to rank the companies financed and to establish a credit rating of the loans with the following criteria: companies with a debt ratio of 0.55 or less are qualified as A; companies with a debt ratio between 0.55 and 0.75 are qualified as B; finally, companies with a debt ratio higher than 0.75 are qualified as $C$ : 
Where Liabilities represents the obligations of the enterprise arising from past events, the settlement of which is expected to result in an outflow of profits from the enterprise; moreover, the Net Worth represents the total assets minus total outside liabilities of an individual or a company.

Sixth, the interest margin or brokerage margin is applied as a measure to compare the different European financial markets. This margin corresponds to the difference between the interest that financial entities earn for credit investment minus the interest they pay to their clients that deposit money.

\section{Data}

The data sources used in the paper are mainly the loans channelled by a crowdfunding platform in Spain called Arboribus, a database containing 64 loans issued between July 2013 and May 2015 for a value of 2,355,840€ (Table 1).

Table 1

Summary of the database used in this paper $(2013-2015)$

\begin{tabular}{|c|c|c|c|c|c|c|c|c|c|c|}
\hline & $\begin{array}{l}\text { No of } \\
\text { loans }\end{array}$ & $\begin{array}{l}\text { Average } \\
\text { loan } \\
\text { financed }\end{array}$ & $\begin{array}{l}\text { Average } \\
\text { turnover of } \\
\text { financed } \\
\text { firms } \\
\end{array}$ & $\begin{array}{l}\text { Average } \\
\text { employees }\end{array}$ & $\begin{array}{l}\text { Average } \\
\text { term of } \\
\text { the loan }\end{array}$ & $\begin{array}{l}\text { Average } \\
\text { gross } \\
\text { profitability }\end{array}$ & $\begin{array}{l}\text { Average } \\
\text { cost of } \\
\text { opening }\end{array}$ & $\begin{array}{l}\text { Mean term } \\
\text { of } \\
\text { concession }\end{array}$ & $\begin{array}{c}\text { Average } \\
\text { Debt Ratio }\end{array}$ & Guaranteed \\
\hline Unit & $u d$. & $€$ & $€$ & $u d$. & mths & $\%$ & $\%$ & days & $\%$ & $\%$ \\
\hline Data from Arboribus Platform & 64 & 36,810 & $3,264,106$ & 17 & 21 & $7.9 \%$ & $1.4 \%$ & 93 & $65.4 \%$ & $68.8 \%$ \\
\hline
\end{tabular}

Source: Arboribus.

We stress that the number of workers includes both permanent and temporary employees. In reference to the number of loan guarantors, the figure of $68.8 \%$ means that 44 of the 64 loans issued have additional guarantees. Moreover, the mean term of contract concession is the number of days needed to formalise the loan agreement and the mean term is the mean loan maturity, in months. Finally, the gross profitability is equivalent to the cost of capital of the loans, calculated as the weighted average cost.

Other data have been used from other crowdfunding platforms located in different countries with more mature markets such as the United Kingdom or the United States. Finally, when we mention households, we refer to small investors purchasing small amounts of securities for themselves, as opposed to institutional investors. They are also called individual investors or retail investors.

\section{Savings behaviour approach}

Chronically low levels of private and public savings in the US and Europe have generated considerable concern among academics and policymakers (Gale and Scholz, 1994 and Shiller, 2010). Differences between countries are created by multiple factors such as the 
development of the financial system, health and social security programs and income growth. In 2012, US households accounted for $77 \%$ of financial assets, whereas in Spain $66 \%$ of the assets were non-financial, mainly real estate assets (García-Montalvo, 2004; Inverco, 2015).

Moreover, saving is important not just for particular individuals but also for the development of a nation. In 1776, Adam Smith positively correlated the wealth of nations and savings because the countries that save the most accumulate the most capital, that is, additional productive resources. Certainly, encouraging savings is not the only goal of a nation, but it should be one of the most important - especially in European countries with aging populations (Shiller, 2010). The ratio of working people to the retired population, also called the dependency ratio, is approximately 5 to 1 in Europe, and the forecast is that it will fall to 2 to 1 within a few decades.

The OECD (2013) emphasises that in the coming decades the pension expenditure will rise sharply. In Spain it is projected to increase by $35 \%$ by 2060 . Moreover, the mean replacement rate, the percentage of a worker's pre-retirement income that is paid out by a pension program upon retirement, was $68 \%$ (41\% public and $27 \%$ private) in OECD countries while in Spain it was 74\%; the figure is fully refunded by the public system (Ministerio de trabajo y asuntos sociales, 2007).

Given that most people do not save sufficient proportions of their income, governments are obliged to intervene (Gale and Scholz, 1994 and Shiller, 2010). Society, led by governments, should encourage people to save - either by increasing awareness and education or through tax benefits. According to Benartzi and Thaler (2007), people spend very little time on decisions regarding saving and are poorly trained, and so governments are obliged to ensure that the pension system has the resources to provide a sustainable response. In the past, Europeans could rely on social welfare but, as the population boomed and life expectancy increased, this source was lost as a stand-alone solution.

Household savings decisions depend on animal spirits, that is, they are irrational (Akerlof and Shiller, 2010). Governments should be aware that individuals balance their savings and investments in a a rational approach, as advocated by conventional economic theory (Modigliani and Brumberg, 1954 and Friedman, 1957). In fact, according to the lifecycle theory, as age increases the need for supplementation a close situation is progressively evident (Rey, Palomo, Gutiérrez, 2013). And since personal savings cover not only savings accounts but also individual retirement accounts, annuities, mutual funds, and any additional investments made by an individual, it is not easy for households to maximise their investment portfolio.

Individuals need to be aware of the possibilities of all the investment products that might optimise their investment portfolio. With this objective in mind, below we compare traditional saving products with an innovative investment alternative called loan-basedcrowdfunding.

\section{Analysis of loan-based crowdfunding as a savings product}

\subsection{Legislation}

Crowdfunding platforms are being legislated around in recent years, that is, in the US in 2012, in the UK, Belgium and Netherlands in 2014 and in Spain in 2015 through the Act 5/2015 of April 27, on Promoting Business Finance, a title known as the "Spanish 


\section{Crowdfunding Act".}

The aim of crowdfunding legislations corresponds to balance investors' protection with the boost of alternative funding and investment.

On the one hand, the law introduces minimum information requirements of both, of the crowdfunding platform and the financed company. Moreover, it is mandatory to identify the risks involved in order to guarantee the transparency and to reduce agency costs.

On the other hand, crowdfunding laws attempt to be flexible enough to attract investments through these new platforms. With this aim, the law differentiate between two types of investors, the professional or accredited investors and retail or non-accredited investors, limiting the amount of investment per year to the second ones. Investors protection is justified considering that default risk in loan-based crowdfunding assets is assumed by investors.

\subsection{Loan-based crowdfunding profitability}

Steinberg and DeMaria (2012) define loan-based crowdfunding as the process of channelling resources through the general public who provide organisations with funds in order to cover their financial needs. In other words, crowdfunding mobilises financial resources which are channelled through new information technologies and provided by a large number of investors, ranging from small investors to large funds, to companies, predominantly to SMEs.

As a result, crowdfunding provides investors with a new disintermediated debt vehicle with a competitive return risk ratio in comparison with other investment products (Haldane, 2013, European Commission, 2014a and 2014b).

In the US and the UK, crowdfunding platforms are well established and, in relation to their product life-cycle, are currently growing fast. On the other hand, in Europe (with the exception of the UK), Oceania and Japan, the crowdfunding industry is in the introduction phase (the liability of newness), with managed loans amounting to 2.7 billions in 2012.

According to Levy (2013) loan-based crowdfunding is at a "tipping point where it will move out from its current base of early adopters, and into the mainstream". Nevertheless, traditional financial entities have analysed crowdfunding from a competitive perspective and, while some are sceptical about its future (The Economist, 2014), others such as BBVA Research (2013) consider that "there is a real risk that banks stop being the primary source for personal and small-business loans".

During the last few months, progress has been made in several countries with regard to the legislation on loan-based crowdfunding. The new Spanish regulations seem to be able to provide legal certainty to investors and thus help to create a virtuous cycle for developing this innovative investment and finance vehicle (Roig and Soriano, 2015).

Moreover, crowdfunding is not just an alternative investment and finance product but is also a promoter of the labour market. As such, it deserves support from public institutions (Ramos et al, 2013). Private investors are expected to increase their asset allocations to loanbased crowdfunding as it matures, but its sustained growth will depend on the financial culture.

\subsection{Loan-based crowdfunding returns}


Reproducing the historical data of the crowdfunding platform Arboribus, Table 2 presents the gross return segmented into three credit rating levels.

Table 2

Loan-Based Crowdfunding Gross return according to its credit rating $(2013-2014)$

\begin{tabular}{ccccc}
\hline & A & B & C & $\begin{array}{c}\text { Weighted } \\
\text { Average }\end{array}$ \\
\hline Average Gross Return & $7.3 \%$ & $7.7 \%$ & $8.1 \%$ & $7.9 \%$ \\
\hline
\end{tabular}

Source: Compiled by the authors.

In order to obtain the net return before taxes, $1 \%$ should be deducted for management fees. The returns obtained from the Arboribus platform are consistent with those of other global leader platforms such as FundingCircle or RateSetter, which report average net returns of $6.8 \%$ and $6.6 \%$ respectively.

Table 3 presents the average return of the last 100 loans issued by the UK platform FundingCircle. In this platform, all investors that have lent for at least one year and to 100 businesses equally are currently earning a positive return. Moreover, 58\% of investors who are lending to at least 100 businesses (with a maximum exposure of $1 \%$ of their total lending to any one business) have earned an average yearly return of more than $6 \%$ after fees and bad debts.

Table 3

Loan-Based Crowdfunding Gross return according to credit rating

\begin{tabular}{lccc} 
& Minimum & Mean & Maximum \\
\hline $\mathrm{A}+$ & $6.0 \%$ & $8.2 \%$ & $11.6 \%$ \\
$\mathrm{~A}$ & $8.0 \%$ & $9.5 \%$ & $13.8 \%$ \\
\hline $\mathrm{B}$ & $9.0 \%$ & $10.1 \%$ & $13.9 \%$ \\
\hline $\mathrm{C}$ & $10.2 \%$ & $11.4 \%$ & $15.0 \%$ \\
\hline $\mathrm{C}-$ & $12.2 . \%$ & $13.0 \%$ & $15.0 \%$ \\
\hline
\end{tabular}

Source: FundingCircle

\subsection{Loan-Based Crowdfunding risks}

Although loan-based crowdfunding is an interesting vehicle for improving a portfolio, investors should be aware that different platforms and loans carry different levels of risk and that they involve a higher risk than holding money on deposits. However, crowdfunding platforms may offer higher returns than those available from other financial products. Legislation is being introduced with two main objectives in mind: to secure an appropriate degree of protection for consumers, and to promote effective competition, also in the interests of consumers.

Moreover, loan-based crowdfunding is not a liquid investment since not all crowdfunding platforms have a secondary market. As a result, investors may not always be able to cash their investment in quickly or for as much money as they paid. Moreover, most investments are in SME debt securities; if the firms default, the capital invested will not be repaid and/or dividend or premiums will not be paid (Financial Conduct Authority, 2014). 
Calculated using the expressions in the methodology, data and hypothesis section, the loan-based crowdfunding risk is moderate at $0.63 \%$. Note that the dataset used refers to up-todate loans.

In order to establish realistic and reliable scenarios, we analyse the impact of bad debt on the return of this innovative product with the assumption of a default ratio based on current data from the FundingCircle.

Table 4

Default Ratio segmented by the credit rating of FundingCircle

\begin{tabular}{rcccccc} 
& A & A & B & C & C- & Average \\
\hline Estimated Default Ratio & $0.6 \%$ & $1.5 \%$ & $2.3 \%$ & $3.3 \%$ & $5.0 \%$ & $2.0 \%$ \\
Actual Default Ratio & $0.1 \%$ & $1.3 \%$ & $2.1 \%$ & $2.5 \%$ & $2.4 \%$ & $1.5 \%$ \\
\hline Estimated Long Term Default Ratio & $1.2 \%$ & $3.1 \%$ & $4.8 \%$ & $7.0 \%$ & $11.0 \%$ & $4.2 \%$ \\
\hline
\end{tabular}

Source: FundingCircle

Table 5 presents the expected return obtained according to the different scenarios of default rate, concluding that the maximum default ratio in order to recover the amount invested is $7.4 \%$.

Table 5

Loan-Based Crowdfunding Gross Return in Correlation to Estimated Default Rate

\begin{tabular}{cccccc}
\hline & $\begin{array}{c}\text { Default Rate } \\
0.0 \%\end{array}$ & $\begin{array}{c}\text { Default Rate } \\
2.0 \%\end{array}$ & Default Rate $4.2 \%$ & $\begin{array}{c}\text { Default } \\
\text { Rate } 5.5 \%\end{array}$ & $\begin{array}{c}\text { Default } \\
\text { Rate } 7.4 \%\end{array}$ \\
\hline $\begin{array}{c}\text { Expected Gross } \\
\text { Return }\end{array}$ & $7.9 \%$ & $5.7 \%$ & $3.3 \%$ & $2.0 \%$ & $0.0 \%$ \\
\hline
\end{tabular}

Source: Compiled by authors.

Table 6 shows the default ratio of global reference platforms, proving that the default ratio of those lending to SMEs is moderate.

\section{Table 6}

Default Rate of Crowdfunding Platforms

\begin{tabular}{lcll}
\hline & Default rate & \multicolumn{1}{c}{ Borrower } & Country \\
\hline Prosper & $7.0 \%$ & Private individual & US \\
\hline LendingClub & $4.3 \%$ & Private individual & US \\
\hline Auxmoney & $2.6 \%$ & Private individual & Germany \\
\hline CreditEase & $2.0 \%$ & Private individuals and SMEs & China \\
\hline FundingCircle & $1.4 \%$ & SMEs & UK \\
\hline Afluenta & $1.3 \%$ & Private individuals and SMEs & Argentina \\
\hline RateSetter & $0.3 \%$ & Private individual & UK \\
\hline Zopa & $0.2 \%$ & Private individuals and SMEs & UK \\
\hline Mean & $2.4 \%$ & & \\
\hline
\end{tabular}

Source: Kirby \& Worner (2014) 
However, investors should take into consideration that the default ratio will depend largely on the platform risk policies. In each platform it is crucial to analyse the default rate, the average return and the historical risk (Groves, 2015).

\subsection{Loan-Based Crowdfunding Diversification}

Portfolio diversification establishes that risks can be minimised if the overall amount expected to be invested is distributed in a pool of assets with behaviours that are hardly correlated or not correlated at all, resulting in an overall risk-profile for the portfolio that is lower than the sum of each of the risks of the assets.

Since customer profiles are diverse, and the predominant figure is the non-professional small investor (Rubinton, 2011) the use of sophisticated tools for the management of its investment portfolio is not expected. Moreover, DeMiguel et al (2009) and Benartzi and Thaler (2007) found evidence that naive diversification is an efficient investment strategy in terms of profit and risk; this strategy consists in diversifying a portfolio by distributing the savings as $1 / \mathrm{n}, \mathrm{n}$ being the investment options available in the market, corresponding to the following equation:

$$
\text { LoanInvestment }=\frac{\text { TotalInvestment }}{\text { NumberofLoans }}
$$

From the mathematical expression defined in the methodology, data, and hypothesis section, the risk of a loan-based crowdfunding portfolio is determined with the same amount invested in $\mathrm{n}$ loans (Table 7):

\section{Table 7}

Diversification of a loan-based crowdfunding portfolio: number of loans invested in relation to the risk of the portfolio

\begin{tabular}{rrrrrrrrrrrrrrrrr}
\hline & 1 & 2 & 3 & 4 & 5 & 6 & 7 & 8 & 9 & 10 & 15 & 20 & 30 & 40 \\
\hline Risk & $0.63 \%$ & $0.45 \%$ & $0.36 \%$ & $0.31 \%$ & $0.28 \%$ & $0.26 \%$ & $0.24 \%$ & $0.22 \%$ & $0.21 \%$ & $0.20 \%$ & $0.16 \%$ & $0.14 \%$ & $0.11 \%$ & $0.10 \%$ \\
\hline
\end{tabular}

Source: Compiled by authors.

As can be seen in Table 8, the fewer the loans invested, the wider the return distribution resulting in a higher risk. Furthermore, the greater diversification, the more the return distribution moves towards a positive asymmetrical distribution, reducing the risk of obtaining negative returns.

\section{Table 8}


Net returns distribution in relation to diversification ${ }^{1}$

\begin{tabular}{|c|c|c|c|c|c|c|c|}
\hline & $\mathrm{R}<0 \%$ & $\begin{array}{c}0 \%>\mathrm{R}>2 \\
\%\end{array}$ & $\begin{array}{c}2 \%>\mathrm{R}>4 \\
\%\end{array}$ & $4 \%>\mathrm{R}>6 \%$ & $\begin{array}{c}6 \%>\mathrm{R}>8 \\
\%\end{array}$ & $\begin{array}{c}8 \%>\mathrm{R}>1 \\
0 \%\end{array}$ & $\mathrm{R}>10 \%$ \\
\hline $\begin{array}{l}\text { Profitability of a portfolio with } 100 \text { loans and an } \\
\text { exposure of } 1 \%\end{array}$ & $0.00 \%$ & $0.00 \%$ & $1.20 \%$ & $38.00 \%$ & $48.00 \%$ & $11.00 \%$ & $1.00 \%$ \\
\hline $\begin{array}{l}\text { Profitability of a portfolio with } 50 \text { loans and an } \\
\text { exposure of } 2 \%\end{array}$ & $0.00 \%$ & $0.20 \%$ & $3.00 \%$ & $37.00 \%$ & $44.00 \%$ & $12.00 \%$ & $3.00 \%$ \\
\hline $\begin{array}{l}\text { Net profitability of a portfolio with } 10 \text { loans and an } \\
\text { exposure of } 10 \%\end{array}$ & $0.40 \%$ & $1.50 \%$ & $7.00 \%$ & $35.00 \%$ & $40.00 \%$ & $12.00 \%$ & $4.00 \%$ \\
\hline
\end{tabular}

Source: FundingCircle

\subsection{Drivers of loan-based crowdfunding performance}

With the aim of identifying the drivers that influence the loan-based crowdfunding returns, we perform a multiple linear regression, taking the dependent variable as the average gross return and the independent variables the business sector of the funded company, the number of years since its establishment and its turnover, the maturity of the loan, the number of employees, the amount funded, the debt ratio, the location of the company headquarters, the loan motivation and the guarantees provided. During the modelling process, we discard certain independent variables due to their high degree of co-linearity, resulting in the selection of six independent variables.

The expression that determines the loan return is presented below. The regression presents a satisfactory adjustment due to the goodness-of-fit test $(\mathrm{R})$ counts with a value of 0.77; furthermore, the standard error of the estimate, a statistical term that measures the accuracy with which a sample represents a population, has a value of $0.79 \%$, and so we conclude that the model is robust. Moreover, using analysis of variance, the significance of the model is contrasted with the F-statistics and the critical value (Sig.).

Average Gross Return of the Loans $=+0.04+0.0000946 \cdot$ NumberEmployees +
$0.0000003865 \cdot$ AmountFunded $+0.001 \cdot$ Maturity $+0.013 \cdot$ DebtRatio +
$0.003 \cdot$ Guarantee $-0.0000000002338 \cdot$ Turnover

Where the Average gross return represents the interest rate resulting from the auction, the NumberEmployees the employees hired by the firm, the AmountFunded the total funded in an auction, the Maturity the loan maturity in months, the DebtRatio the debt ratio of the firm financed the Guarantee the 1 is assigned in cases with third party loans and 2 in cases without additional guarantees and the Turnover: sales reported by the firm in its accounts.

Furthermore, we emphasise that the business sector, the location and the loan motivation do not contribute substantially to explaining the loan return; therefore, they are not considered in the resulting model.

Among the selected drivers, the loan amount, the maturity and the debt ratio, in this order, are the ones that correlate most with the dependent variable. However, other drivers

\footnotetext{
${ }^{1}$ The data source corresponds to FundingCircle, which has a sample of 28,041 investors that have funded companies for at least 360 days.
} 
such as the turnover of the funded company, the additional guarantees and the number of the employees also affect the loan return.

To summarise, as social security coverage diminishes, the general public should take care to save enough for their retirement. As a result, the constitution of a diversified portfolio should be a responsibility, more than a recommendation. And familiarity with the various investment products available in the market is the key to a successful retirement with an acceptable level of savings. Public pension systems were created due to the reasonable doubts about the capacity of individuals to save sufficiently over the life-cycle, in view of their irrational decisions and lack of foresight and preparation. Today, individuals can no longer rely on the public system to provide a secure income for retirement.

\section{Analysis of traditional saving products}

Individuals need to know the differences between the investment products available in order to make proper financial decisions. However, Breuer and Salzmann (2012) reported a widespread lack of financial culture in society as a whole. To address this situation, Shiller and Kroszner (2013) advocated government subsidising of impartial, fee-only, dedicated financial advisors to encourage their consultation by people at all income levels; that is, someone with an uncompromised relation with the client and therefore someone whom the client can turn to for disinterested and sympathetic advice.

Moreover, Warren (2008) recommended the creation of an agency to collect data on the financial products that are least understood, the kinds of disclosures that are most effective, and the products that are most likely to result in consumer default.

In the next section we analyse traditional saving products in order to be able to compare them with the loan-based crowdfunding investment product.

\subsection{Bank Deposits}

The financial structure of Spanish households is characterised by a large-scale assignment of funds to bank deposits. However, the low profitability of this product due to the low interest rate set by the European Central Bank has meant that individuals now hold a higher proportion of more risky assets with a larger exposure to financial markets (Inverco, 2015).

Table 9 identifies the weighted average interest rate (gross return) as well as a comparison of the interest margin between Spain and the EuroZone. It can be seen that the Spanish financial market has a high competitiveness gap, because Spanish financial customers obtain less for their investments and pay more for their credit.

\section{Table 9}

Interest Rates Applied by Financial Institutions - June 2014.

\begin{tabular}{lcc}
\hline & Spain & Eurozone \\
\hline One year deposit & $0.86 \%$ & $1.32 \%$ \\
\hline Deposits between 1 and 5 years & $9.60 \%$ & $5.89 \%$ \\
\hline Interest margin & $8.74 \%$ & $4.57 \%$ \\
\hline
\end{tabular}


In spite of the above, investors should be aware of the intrinsic risks of savings assets. While bank deposits offer the guarantee of the bank itself and are also covered by the Deposit Guarantee Fund up to the sum of 100,000 €, loan-based crowdfunding has the sole guarantee of the financed Company itself.

\subsection{Disintermediated banking products}

The presence of investment funds, saving plans, insurance (that is, disintermediated banking products), and direct investment increased considerably in households portfolios during 2014. These products now represent $54.1 \%$ of Spanish household financial portfolios, compared with $47.9 \%$ in 2012 .

However, the savings portfolio of Spanish households shows a significantly lower exposure to pension funds and insurance than elsewhere (16.5\% vs. $38 \%$ in the Eurozone), a higher proportion of bank deposits (46.8\% vs. $33.2 \%$ in the Eurozone) and a lower proportion of investment funds and quoted shares (16.4\% vs. 19.4\% in the Eurozone) (Fundación de Estudios Financieros, 2010).

\subsection{Equity investment: stock market}

In 2014, Spanish households owned $26.2 \%$ of the Spanish security market. This was the largest rate over the last 12 years, and a figure far ahead of the corresponding proportion in the Eurozone (11.2\%) (Bolsa y Mercados Españoles, 2015).

Table 10 shows the profitability and risk of Spanish quoted shares. Note the considerable volatility that Spanish households accept while investing in the Spanish stock market security market.

Table 10

Profitability and Risk on the IBEX-35 Selective Index of the Spanish stock market.

\begin{tabular}{|c|c|c|c|c|c|c|c|c|c|c|c|c|c|c|}
\hline & $\begin{array}{l}\text { Mean } \\
2002- \\
2014 \\
\end{array}$ & 2002 & 2003 & 2004 & 2005 & 2006 & 2007 & 2008 & 2009 & 2010 & 2011 & 2012 & 2013 & 2014 \\
\hline Profitability IBEX 35 (\%) & $6,25 \%$ & $-28,11 \%$ & $28,17 \%$ & $17,37 \%$ & $18,20 \%$ & $31,79 \%$ & $7,32 \%$ & $-39,43 \%$ & $29,84 \%$ & $-17,43 \%$ & $13,11 \%$ & $-4,66 \%$ & $21,42 \%$ & $3,66 \%$ \\
\hline
\end{tabular}

1) Risk calculated on the basis of the volatility of the profitability.

Source: Bolsas y Mercados Españoles

To summarise, Spanish households are investing in the stock market as an alternative way to improve their profit and the risk trade-off of their savings portfolio, given the demonstrable inefficiency (in comparison with other mature markets) of the Spanish financial market. However, as it has been shown, the stock market risk is significant and so other alternative investment products should be made available for Spanish households.

\subsection{Investment funds}


As stated above, Spanish households are assuming risks in order to enhance the profits of their portfolios. In fact, investment funds are currently the asset with the highest allocation, exceeding the insurance and stock market by four times (Inverco, 2015).

However, the average return of investment funds during the last 15 years was $1.98 \%$, below the rate for 15-year Spanish government bonds and the investment in the IBEX-35 stock market (44\%). Moreover, only 26 of the 614 funds analysed had a higher level of profitability than 15-year Spanish government bonds and only 38 had been more profitable than the stock market. Fifty-two had negative returns (Fernandez, Linares and Fernandez Acín, 2014a).

Therefore, households' use of investment funds should be analysed carefully due to the great volatility of these products, the importance of management and also the fund fees.

\subsection{Pension plans}

The total pension replacement rate is $67.9 \%$ in the OECD countries (public pensions comprise $40.6 \%$, compulsory private pensions $13.4 \%$, and voluntary private pensions $13.9 \%$ ). Pension fund assets account for $84.2 \%$ of GDP. In Spain, although the replacement rate is $73.9 \%$, pension plan assets correspond to $9 \%$ of GDP, a driver that reflects the degree of development of a country's pension system plans and clearly shows that a great deal remains to be done in this important area. The Spanish public pension system absorbs almost all the costs and represents the highest percentage of all OECD countries with the exception of Austria (OECD, 2013 and Martí, Matallín and Fernández, 2008).

Nonetheless, Spaniards of all socio-economic levels are increasing their allocation to pension funds. The mean gross wage of investors in this asset is below $42,000 €$ in $77.8 \%$ of cases, and below 60,000 $€$ in $89.9 \%$ (Inverco, 2015).

This is good news, seeing that the future of public pension funds is in doubt and also, from a world perspective, pension fund assets presented an average annual increase of $9.1 \%$ between 2009 and 2013. Doubts regarding the future of public pension funds are mainly due to the fact that the population is ageing, thus causing a significant increase in public pension expenditure; in Spain, the forecast increase between 2013 and 2060 is 35\% (OECD, 2013). Moreover, $36 \%$ of the investors in pension funds in Spain are under the age of 45, and $46 \%$ are between 46 and 60. In view of the above, and also in view of public budget constraints, individuals need to pay more attention to their future incomes, and a large increase in pension funds in Spain can be foreseen (Martí and Matallín, 2008).

As for pension fund profitability, from a global perspective Ferreira et al (2012) found that mutual funds around the world were underperforming. However, the performance of these funds was explained by country characteristics: that is, these authors found a positive relation between fund's performance and a country's level of financial development, especially stock market liquidity. Furthermore, domestic funds located in countries with stronger legal institutions, better investor protection, and more rigorous law enforcement tended to perform better. Ferreira et al concluded that the home trading and the legal environments are important in explaining mutual fund performance across countries.

From a Spanish perspective, between 1998 and 2013, the average annual return of pension funds was $1.53 \%$. Twenty-five had a negative return; only four performed better than the IBEX 35 and only three exceeded the return of 15-year Spanish government bonds (Fernandez, Linares and Fernandez Acín, 2014b). 
Moreover, during the last 10 years, $93 \%$ of the pension funds obtained returns lower than inflation and $99.3 \%$ did not exceed the return of 10-year government bonds. These results highlight the need to professionalise management, but it should be borne in mind that pension fund members are also interested in tax savings. Table 11 displays a calculation of tax savings for a pension fund allocation of $8,000 €$ in a given year.

\section{Table 11}

Fiscal savings through pension fund investment.

\begin{tabular}{cccccccccc}
\hline & $\begin{array}{c}\text { Mean } \\
\text { gross } \\
\text { income }\end{array}$ & $\begin{array}{c}\text { Taxable } \\
\text { base }\end{array}$ & Tax rate & $\begin{array}{c}\text { Net tax } \\
\text { payable }\end{array}$ & $\begin{array}{c}\text { Pension } \\
\text { fund } \\
\text { contribution }\end{array}$ & $\begin{array}{c}\text { Net } \\
\text { taxable } \\
\text { base }\end{array}$ & Tax rate & $\begin{array}{c}\text { Net tax } \\
\text { payable }\end{array}$ & $\begin{array}{c}\text { Tax } \\
\text { saving }\end{array}$ \\
\hline $\mathrm{N}^{\mathrm{o}}$ plans & $28,275.00$ & $28,275.00$ & $16.4 \%$ & $4,642.00$ & $8,000.00$ & $20.275,00$ & $12.4 \%$ & $2,514.00$ & $2,128.00$ \\
\hline
\end{tabular}

1) Mean gross national income (GNI) in Spain in 2013 according to the World Bank, converted into Euros. GNI is the total domestic and foreign income of the residents of a country, consisting of gross domestic product (GDP) plus net income from abroad. So while GDP measures production inside the country, without considering who produces it, GNI measures the value of income of the residents without considering where it is produced.

Source: Compiled by the authors.

The average annual return of pension funds prior to withdrawal is $28.1 \%$ (Table 12 ).

\section{Table 12.}

Pension fund profitability prior to withdrawal

\begin{tabular}{lccccc}
\hline & Investment & $\begin{array}{c}\text { Mean } \\
\text { profitability }\end{array}$ & Tax saving & $\begin{array}{c}\text { Total annual } \\
\text { profitability }\end{array}$ & $\begin{array}{c}\text { Total annual } \\
\text { profitability } \\
(\%)\end{array}$ \\
\hline Pension fund & $8,000.00$ & $1.53 \%$ & $2,128.00$ & $2,250.40$ & $28.1 \%$ \\
\hline
\end{tabular}

Source: Compiled by the authors.

Table 13 shows the return on a contribution of $8,000 €$ to a pension fund taking into account tax savings and the profitability of the pension fund itself during a 10-year period and before withdrawal of the amount invested (as pension fund members are taxed on withdrawing their money).

\section{Table 13}

Pension fund performance prior to withdrawal.

\begin{tabular}{lccccccccccc}
\hline \multicolumn{1}{c}{ Year } & $\mathbf{0}$ & $\mathbf{1}$ & $\mathbf{2}$ & $\mathbf{3}$ & $\mathbf{4}$ & $\mathbf{5}$ & $\mathbf{6}$ & $\mathbf{7}$ & $\mathbf{8}$ & $\mathbf{9}$ & $\mathbf{1 0}$ \\
\hline Pension fund & 8,000 & 10,250 & 10,566 & 11,059 & 11,751 & 12,678 & 13,888 & 15,445 & 17,440 & 19,994 & 23,272 \\
\hline Return* & & 2,250 & 316 & 492 & 692 & 927 & 1,209 & 1,557 & 1,995 & 2,554 & 3,278 \\
\hline
\end{tabular}

*) The return obtained in year 1 includes the tax savings and the return obtained on the investment in the pension fund. From year 2 onwards, to calculate the return obtained, the reinvestment of the returns on previous years is included in the fund's mean profitability.

Table 14 calculates the profitability after withdrawing the investment from the fund 
(attracting tax).

Table 14

Performance of a pension fund after withdrawal

\begin{tabular}{lcccccc}
\hline & $\begin{array}{c}\text { Return on } \\
\text { pension fund } \\
\text { at year 10 }\end{array}$ & Taxable base & Tax rate & $\begin{array}{c}\text { Net tax } \\
\text { payable }\end{array}$ & Net return $\begin{array}{c}\text { Profitability } \\
\text { after 10 years: } \\
\text { Investment of } \\
8,000 €\end{array}$ \\
\hline Pension plan & $23,272.21$ & $23,272,21$ & $13.8 \%$ & $3,216.20$ & $20,056.01$ & $9.6 \%$ \\
\hline
\end{tabular}

Source: Compiled by the authors.

In summary, the expected return of a 10-year investment in a pension plan corresponds to $9.6 \%$ on the assumption that the amount saved is reinvested due to the tax incentives. According to Luque (2012), pension funds are more profitable when the tax saved is reinvested.

Considering the scarcity of savings in Europe, it should be a duty for states, rather than just a recommendation, to incentivise planning for retirement. According to the General Insurance and Pension Funds Directorate, only 17\% of Spaniards have pension funds, with an average investment of 8,169 $€$ in 2014 (Inverco, 2015). What is more, 76\% of households save less than 300 euros per year; the mean annual figure for savings is 1,375 euros (Dirección General de Seguros y Fondos de Pensiones, 2012).

Households should be alert to the requirements of pension plans - for example, the fact that they cannot redeem the amount invested before retirement. Pension funds are an interesting investment product due to their fiscal incentives. In Spain, however, the investment is only tax deductible up to $8,000 €$, a very low figure. Given the lack of any fiscal incentive above $8,000 €$, and in the absence of fiscal asymmetry, pension funds are similar products to investment funds.

This reduced efficiency impacts mainly small investors, households and SMEs with low bargaining power. As a result, interest in alternative investment products such as loan-based crowdfunding is growing. Crowdfunding is a disruptive technology that can help to democratise the financial systems. According to Shiller, "we need to democratise finance and bring the advantages enjoyed by the clients of Wall Street to the customers of Walmart" (Shiller, 2009).

States should consider the possibility of offering tax breaks to investors in loan-based crowdfunding who see this financing method as a way to obtain a retirement pension. The advantages could be significant: on the one hand, it could reduce the system's dependence on banks, which is particularly high in Europe (Cummings, 2013); on the other, it would go some way to resolving the problem of asymmetrical information that impacts the credit availability to SMEs (OECD, 2014). Therefore, states should consider the possibility of regulating investment in SMEs through crowdfunding.

\section{Comparison between loan-based crowdfunding and traditional savings products}

Financial institutions' interest margin has reached a historically high level (Moldow, 2014). On the one hand, companies face high capital costs - especially the SME segment, whose interest rate is approximately twice that of the large firm segment (that is, 211 points). 
On the other hand, investors, especially households, with little access to alternative investment products, are obtaining historically low interest rates for their deposits. This is particularly relevant in the Spanish market where alternative finance represents only $20 \%$ of the total compared with 50\% in France or Germany (Giralt \& González, 2012).

In addition, from a global financial market perspective, European households have a less competitive financial framework than American households, resulting in fewer possibilities to allocate their resources; this has an impact on their portfolio returns (Deutsche Bank Research, 2004 and Haldane, 2013). Moreover, in contrast to the American financial market, the European market is highly dependent on the financial system; while in the US long-term financing represents $19 \%$ of the total, in Europe it represents $81 \%$ (Cummings, 2013). Furthermore, European markets face a shortage of safe assets ${ }^{2}$, which has a negative impact on the performance of savings portfolios due to the high demand and fallings prices.

In summary, in this scenario of a high interest margin which reduces the performance of deposits, the relatively high volatility of investment funds and stocks, the scarcity of safe assets resulting in high demand and reduced interest rates, and the effect on the small investors or households with few investment alternatives, crowdfunding platforms are beginning to penetrate the financial markets.

These platforms transact SME debt, enabling households to earn the interest margin but assuming the risk of the debt. Investors should carefully analyse the platform's historical performance data and the company financed, and they should diversify their debt investment among several SMEs in order to reduce risks (Roig and Soriano, 2015).

The decision of investors to allocate their savings in loan-based crowdfunding will depend, to a large extent, on the relation between profitability and the risk of each asset available for investment. Table 15 presents the data for traditional assets analysed earlier in this paper.

Table 15

Comparison of investment products $(2012-2014)$

\begin{tabular}{cccccc}
\hline $\begin{array}{c}\text { One Year } \\
\text { Deposit }\end{array}$ & $\begin{array}{c}\text { Deposits between 1 } \\
\text { and 5 years }\end{array}$ & IBEX 35 & $\begin{array}{c}\text { Investment } \\
\text { funds }\end{array}$ & $\begin{array}{c}\text { Pension } \\
\text { funds }\end{array}$ & $\begin{array}{c}\text { Loan-Based } \\
\text { Crowdfunding }\end{array}$ \\
\hline $0,86 \%$ & $9,60 \%$ & $6,25 \%$ & $1,98 \%$ & $9,60 \%$ & $7,90 \%$
\end{tabular}

Source: Compiled by the authors.

However, this table does not report the risk of all assets (presented in section 5). In this connection, the weighted average return of the investment funds was relatively high between 2012 and 2014; from a five-year perspective it corresponds to $3.17 \%$ and from a fifteen-year perspective it is $1.66 \%$ with its implied volatility.

On the other hand, real estate investment involves a considerable commitment, which makes it difficult to compare with loan-based crowdfunding. Taking into account the asset value and the return on rents, it has presented significant volatility in recent years.

Before examining loan-based crowdfunding data, it is important to summarise the

\footnotetext{
${ }^{2}$ The concept "safe assets" corresponds to financial products that are expected to have a very low level of credit and liquidity risk; most of them are sovereign debt securities issued by countries of proven solvency and institutional stability.
} 
results obtained for pension funds. These are savings assets which usually offer a fiscal incentive, leading to a fiscal asymmetry in their favour. Investors should study the performance of pension schemes, including the fiscal incentives; this is because these schemes depend on political decisions which may vary between states. In our analysis of pension scheme performance we considered the fiscal incentive.

Regarding loan-based crowdfunding, the mean weighted profitability and risk calculated in sections 4.2 and 4.3 were $7.9 \%$ and $0.63 \%$ respectively. The results show that loan-based crowdfunding has an efficient risk return rate which can notably improve a savings portfolio. Moreover, in contrast to traditional products that pay the principle at loan maturity, SMEs financed by crowdfunding repay the loan with capital and interest, which increases the possibility of reinvesting the money returned and reduces the uncertainty.

Due to recent regulations, the favourable results and the context of low interest rates, crowdfunding can initiate a positive cycle. However, Spanish households allocate $66 \%$ of their portfolio to non-financial assets, mainly real estate assets; $53 \%$ of them have only one financial asset and only $18 \%$ have three or more (García-Montalvo, 2004).

In this scenario of a scarcity of savings products with a competitive relationship between profitability and risk, crowdfunding can represent a significant improvement over retirement schemes and emerges as a disruptive technology (truCrowd, 2013). Loan-based crowdfunding enables households to take charge of their retirement funds and dramatically improving the financial markets by means of innovation and entrepreneurship. It has a democratising and humanising effect on finance (Shiller, Kroszner, 2013).

\section{Conclusions}

The financial crisis has pushed interest margins to historical highs and has had a negative impact on companies' capital costs and on the performance of savings products. Moreover, the scarcity of saving products, especially for small investors, reduces their capacity to improve their portfolios. Traditional investment products do not really respond to the needs of retail investors because interest rates on deposits are at a historically low level, resulting in low returns. This directly impacts conservative households trying to increase the efficiency of their portfolio by investing in investment funds or structured investment vehicles; however, those investments, as evidenced by the results of the last decade, present significant volatility and, depending on the investor's profile, may be a valid destination for part of a savings portfolio.

Pension funds are an interesting investment product due to their fiscal incentives. In Spain, amounts invested in pension funds up to a maximum of $8,000 €$ per year are tax deductible. However, households should be aware of the product withdrawal constraints, such as the impossibility of redeeming the amount invested before retirement. The expected return of a 10-year investment in a pension scheme, for this maximum amount, corresponds to $9.6 \%$ on the assumption that the amount saved due to the tax incentive is reinvested. As a result, investing in pension funds is interesting up to the annual limit of 8,000 $€$, but not beyond.

In this context of a low relationship between profitability and risk of traditional products, added to scarcity of safe assets in the small investors segment, disruptive technologies such as loan-based crowdfunding platforms are entering the market. Loan-based crowdfunding offers a competitive profitability-risk combination, with a real return of $7.9 \%$ and a real risk of $0.63 \%$. With a default rate scenario of $2.0 \%$ (above that expected by equivalent platforms 
such as FundingCircle) the expected return would be 5.4\%.

Investors should pay attention on default ratios which will depend largely on the platform risk policies considering that, unlike deposits, the default risk in loan-based crowdfunding assets is assumed by investors. As a consequence, diversification of loans is recommended in order to reduce risk.

States should consider the possibility of offering tax breaks to investors in loan-based crowdfunding as a way to reduce the system's dependence on banks and increase the availability of credit for SMEs. Considering the scarcity of savings in Europe, it should be a duty rather than a recommendation for states to incentivise planning for retirement

The introduction of these innovative products is the result of using the crisis to improve our financial markets by means of innovation and entrepreneurship. It has a democratising and humanising effect on finance.

\section{References}

Akerlof, G. A.; Shiller, R. J. (2010). Animal spirits: How human psychology drives the economy, and why it matters for global capitalism. Princeton University Press.

Bank of Spain (2015). Tipos de Interés. Available at: http://goo.gl/3Ffpcs

BBVA Research (2013). Crowdfunding: A sustainable alternative to traditional banking? Economic Outlook.

Benartzi, S.; Thaler, R. H. (2007). Heuristics and biases in retirement savings behavior. The journal of economic perspectives, pp. 81-104.

Bolsa y Mercados Españoles (2015); Los Inversores Extranjeros Marcan Récord y las Familias Siguen Aumentando su Peso como Propietarios de las Empresas de la Bolsa Española. Available at: http://goo.gl/Pv82Og

Bonin, J.; Wachtel, P. (2003). Financial sector development in transition economies: Lessons from the first decade. Financial Markets, Institutions \& Instruments, 12(1), pp. 1-66.

Breuer, W.; Salzmann, A. J. (2012). National culture and household finance. Global Economy and Finance Journal, 5, pp. 37-52.

Comisión Europea; Unleashing the potential of Crowdfunding in the European Union. Communication from the Commission to the European Parliament, the Council, the European Economic and Social Committee and the Committee of the Regions; 2014a.

Comisión Europea; Guidelines on State aid to promote risck finance investments; Communication from the Commission; 2014b.

Cummings, C. (2013). Alternative finance for SMES and Mid-Market companies; ARES \& CO, Strategy Consulting. Available at: http://goo.gl/73rInz

DeMiguel, V.; Garlappi, L.; Uppal, R. (2009). Optimal versus naive diversification: How inefficient is the 1/N portfolio strategy?. Review of Financial Studies Vol. 22 (5), pp.19151953.

Deutsche Bank Research (2004); "US financial market more efficient". Available at: https://goo.gl/qTRtsl

Dirección General de Seguros y Fondos de Pensiones (2012). Informe Estadístico de Instrumentos de Previsión Social Complementaria. Available at: http://goo.gl/w3WcP6

Fernandez, P.; Linares, P.; Fernandez Acin, P. (2014a). Profitability De Los Fondos De Inversión En España 1998-2013 (Return of Mutual Funds in Spain 1998-2013). 
Fernandez, Pablo, Pablo Linares, and Pablo Fernandez Acin. "Profitability de los Fondos de Pensiones en España. 1998-2013 (Pension Funds in Spain. 1998-2013)." Available at SSRN 2393382 (2014b).

Ferreira, M. A., Keswani, A., Miguel, A. F., \& Ramos, S. B. (2012). The determinants of mutual fund performance: A cross-country study. Review of Finance, rfs013.

Financial Conduct Authority (2014). Crowdfunding. Available at: http://goo.gl/NRUzLu

Friedman, M. (1957). A Theory of the Consumption. Princeton, NJ: Princeton University Press.

Fundación de Estudios Financieros (2010). Ahorro familiar en España Available at: http://goo.gl/pf9Nia.

Gale, W. G.; Scholz, J. K. (1994). IRAs and household saving. The American Economic Review, 1233-1260.

García-Montalvo, J. Patrimonio inmobiliario y riqueza de la economía española. Revista Económica de Cataluña 48; 2004.

Giralt, A.; González, J. (2012). Financiación de la PyME en el mercado financiero español. La experiencia y proyección del MAB.

Goldsmith RW. (1969). Financial Structure and Development. Yale University Press: New Haven, CT.

Haldane, A. How to rehabilitate securitization, IFLR, 2013. Available at: http://goo.gl/e3x07k

Groves, J. (2015). Chair UK Crowdfunding Association. Interactive Investor. Available at: http://goo.gl/twEQiZ

Inverco (2015). La Inversión en Planes de Pensiones Individuales. Available at: http://goo.gl/109An5

King, R.G., Levine R. (1993). Finance and growth: Schumpeter might be right. Quarterly Journal of Economics 108(3), pp. 717-37.

Kirby, E.; Worner, S. Crowd-funding: An Infant Industry Growing Fast. OICU-IOSCO; 2014. Available at: http://goo.gl/Z5eEj4

Levy, J. (2013) The P2P Lending Revolution: New Opportunities For Investors And Investment Advisors. Available at: http://goo.gl/wtO2q1

Luque, F. (2012). ¿Fondo de pensiones o Plan de Pensiones?. Morning Star. Available at: http://goo.gl/sa7Id8

Martí Ballester, C.P.; Matallín Sáez, J.C.; Fernández Izquierdo, Mª.A.; (2008). Influencia de la profitability en el proceso de selección de planes de pensiones en España: un análisis de sensibilidad. Revista Española de Financiación y Contabilidad, Vol. XXXVII, nº 138, pp. 279-314.

Ministerio de trabajo y asuntos sociales (2007). Tasa de Sustitución por Hogares del Sistema de Pensiones Español y Movilidad Inducida de Rentas. Available at: http://www.segsocial.es/prdi00/groups/public/documents/binario/100599.pdf

Modigliani, F.; Brumberg, R. (1954). Utility analysis and the consumption function: An interpretation of cross-section data.

MOLDOW, C. (2014). A trillion dollar market by the people, for the people; How marketplace lending will remake banking as we know it. Foundation Capital. Available at: http://goo.gl/tA7ldw.

OECD (2013). Pension at a glance. OECD and G20 Indicators

OECD (2014). Scoreboard: Financing SMEs and Entrepreneurs. Available at: http://goo.gl/Tv4r9C

Ramos, J.; González, B.; Llorca, R.; Mayor, L., Porcel, R. (2013). Micro Finaciación Colectiva (Crowd-Funding): un nuevo instrumento económico para el crecimiento económico y el empleo: Un análisis de los efectos económicos de la Micro-financiación 
colectiva con especial énfasis en el caso español. Informe presentado en la conferencia organizada por la Fundació Caatalunya Europa, Ateneu Barcelonès. Available at: http://goo.gl/Pk9lwN

Rey Paredes, V.; Palomo Zurdo, R.; Gutiérrez Fernández, M. (2013). Análisis Cualitativo Sobre la Inversión en Planes de Pensiones en España. Crónica Tributaria, Vol. 147, pp. 203-214.

Roig Hernando, J.; Soriano Llobera, J.M. (2015). Crowdfunding de loans para PyMEs en España: Un análisis empírico. Estudios de Economía Aplicada, Vol 33, pp: 301-318.

Rubinton, B.J. (2011) Crowdfunding: disintermediated investment banking. MPRA Paper $\mathrm{n}^{\circ}$ 31649. Available at: http://goo.gl/pmPJci

Schumpeter, J.A. (1934). The Theory of Economic Development. Harvard University Press: Cambridge, MA.

Shiller, R.J. (2006). The Difference in Saving Rates between China and the U.S. http://economistsview.typepad.com/economistsview/2006/08/differences_in_.html

Shiller, R. J. (2009). The new financial order: Risk in the 21st century. Princeton University Press.

Shiller, R.J. (2010) Encouraging saving: Lessons for developed and developing countries. Available at: http://www.shillerfeeds.com/2010/04/encouraging-saving-lessons-for.html

Shiller, R.J.; Kroszner, R.S. (2013). Reforming U.S. Financial Markets: Reflections Before and Beyond Dodd-Frank. Alvin Hansen Symposium on Public Policy at Harvard University. The MIT Press.

Smith. A. (1776). The wealth of nations.

Steinberg, S.; DeMaria, R. (2012). The Crowdfunding Bible: How to Rise Money for Any Startup, Video Game or Project.

The Economist; We try harder. Pertinent to the printed edition of May $10^{\text {th }} 2014$. Available at: http://goo.gl/EExyaL

truCrowd (2013). Equity Crowdfunding and Retirement. Available at: http://goo.gl/qxZF9m

Valverde, S. C.; Villarroya, J. M. (2010). Diez interrogantes del sector bancario español. Cuadernos de Información Económica 215, pp. 80-105.

Warren, E. (2008). Product safety regulation as a model for financial services regulation. Journal of Consumer Affairs, 42(3), pp. 452-460.

World Economic Forum (2016). 5 ways technology is transforming finance. Available at: https://goo.gl/bQ5rsE 